Article

\title{
The River's Light: Water Needs for Thermoelectric Power Generation in the Ebro River Basin, 1969-2015
}

\author{
Diego Sesma-Martín 1,2 (D) \\ 1 Economics Department, Public University of Navarre, 31006 Pamplona, Spain; diego.sesma@unavarra.es; \\ Tel.: +34-948-169340 \\ 2 Institute for Advanced Research in Business and Economics (INARBE), 31006 Pamplona, Spain
}

Received: 19 December 2018; Accepted: 22 February 2019; Published: 28 February 2019

\begin{abstract}
Water is essential for almost all energy processes. This paper analyses the evolution of the cooling water needs of thermal power plants in the Ebro River basin, the largest contributor to the Spanish electricity grid, over the period 1969-2015. It makes several contributions. First, the cooling water needs for the plants are estimated. Second, these water requirements are compared to other water-using activities in the region. Third, a long-term water-use efficiency analysis is carried out. Finally, water-saving measures are proposed to counter possible future water scarcities. The results show that thermoelectric water consumption per capita is around $7 \mathrm{~m}^{3} /$ year. Estimated future thermal power generation water withdrawals (around $500 \mathrm{~m}^{3}$ per capita/year) might compromise flows for other water uses in periods of drought.
\end{abstract}

Keywords: thermoelectricity; water consumption; water withdrawals; cooling technologies; Ebro River

\section{Introduction}

Water is essential for almost all energy generation processes. Electrical power production is one of the largest water-intensive activities worldwide [1]. Growing global concern about this link, known as the 'water-energy nexus', has led to an increase in the number of related studies in the international literature in recent years [2-6]. Most of the research focuses on regions vulnerable to drought, such as Africa, the Middle East, and some areas in the U.S. [7-12]. Other studies examine areas of high population density, such as China, where electricity and, hence, water demand, is expected to rise critically [13-15]. Other studies assess the electricity mix under water scarcity scenarios [16-18].

Water scarcity episodes and heat waves appear to be increasing due to climate change; many areas are already suffering from both these climatic effects, even simultaneously [19]. Similarly, future projections indicate that electricity demand will continue to rise because of population growth. In fact, water is now a constraining factor for power plants across the globe [20]. Given these forecasts, many international institutions, notably the International Energy Agency and the World Bank, have begun to address this issue to ensure the future provision of water and energy. Every year, the International Energy Agency publishes the 'World Energy Outlook' (for more information, see [21]), which provides critical analyses and information on energy demand and supply trends and their implications for energy security, environmental protection and economic development. The World Bank in 2014 launched the 'Thirsty Energy' (for more information, see [22]) initiative to identify interdependencies in the water and energy sectors, to address water and energy challenges, to design evaluation and resource management tools to help coordinate decision-making, and to promote sustainable development $[20,23]$. Other institutions extensively reporting on the water-energy nexus are the US Department of Energy (DOE), the Energy Research Centre of the Netherlands (ECN), and the World Policy Institution [24,25]. 
The relation between water and energy tends to bring to mind hydroelectric facilities. However, not only hydropower plants need water to function. Thermoelectric-power plants, fueled by coal, fuel-oil, gas, and uranium, also need water-freshwater for the most part. For example, in 2005, thermoelectric production accounted for $41 \%$ of freshwater withdrawals in the United States, surpassing even agriculture [26]. Unlike hydroelectric power plants, thermoelectric facilities boil water to create steam to spin turbines that generate electricity. Conventional thermal and nuclear power plants operate on the same principle, but they differ in the way they heat the water. Whereas conventional thermal power stations obtain heat by burning fossil fuels, nuclear power plants obtain it through nuclear reactions. Later, the heat must be dissipated in cooling systems to allow the facilities to operate correctly. The temperature needed to produce electricity differs depending on fuel type and, consequently, each type of thermal power plant requires different amounts of water for cooling. Cooling is the activity that requires the largest amounts of water in the process and, among the current thermoelectric generating technologies, the water needs of nuclear power plants are the largest per megawatt hour generated [27]. In turn, the different types of cooling systems (i.e., wet or dry) require different quantities of water. Thus, whereas dry-cooling systems require minimum volumes of water to cool, the water needs of wet-cooling systems vary greatly. The main wet-cooling systems' designs are open-loop (or once-through cooling) and cooling towers. Open-loop systems remove water from a body of water, pass it through a steam condenser, and subsequently discharge it into the same body of water at a higher temperature (usually limited by environmental law). By contrast, cooling towers expel the waste heat from the cooling water into the atmosphere. As a result, open-loop cooling systems involve higher water withdrawals than cooling towers, while cooling towers have higher water consumption volumes [28]. It is essential to understand the distinction between water withdrawals and water consumption in power generation. According to the US Geological Survey (USGS), water withdrawals are the total volume of water removed from a source (even if it is later partially returned to the flow), and water consumption is the amount of withdrawn water lost to evaporation [26]. Several studies on the energy-water nexus link these concepts to the terminology of the water footprint initially addressed by Hoekstra, among others [29-35]. In this context, the blue water footprint corresponds to the amount of water consumed during the cooling process. Similarly, water withdrawals are indirectly related to the grey water footprint of thermoelectric power plants (see [36] for more information).

This study assesses the water needs for thermoelectric power generation in the Ebro River basin, the most important long-term contributor to Spanish electricity generation. By calculating the water withdrawals and consumption for thermoelectricity generation in the Ebro River basin, this study increases the knowledge about the relationship between water and energy in Spain and bridges a gap in the literature on the matter in this country. There is some isolated research on the matter $[37,38]$, but studies rarely take a long-term perspective and are limited to single technologies [39]. In addition, unlike in other countries, the water-energy nexus is not yet a priority in the Spanish policy agenda. A lack of official statistics and inconsistency in the information sources on the water-energy nexus in Spain could be behind this surprising fact [40]. Furthermore, to increase social awareness of the importance of water as an energy resource, a sectoral comparison and an analysis of the water efficiency of the plants in the Ebro basin is carried out. Finally, an evaluation on the different combinations of power generation technologies and cooling systems is carried out, to offer possible water-saving solutions to future water scarcity scenarios. To sum up, this analysis provides a tool for better decision-making in the implementation of integrated water and energy policies.

How much water is used for thermal power generation in the Ebro River basin? What are the effects on water of the different electricity production methods? Is water really an opportunity cost for alternative uses in this region? Will lack of water limit the region's energy production in the future? These are some of the issues the present study addresses.

The paper is organized as follows. Section 2 highlights the importance of the Ebro River basin for Spain as a whole. Section 3 describes the methodology and data sources. Section 4 presents the 
main findings. The discussion and future research proposals are set out in Section 5. Finally, Section 6 summarizes the main conclusions.

\section{The Ebro River Basin}

Spain has a long history of water management. The first attempt to regulate water use in Spain was the Water Law of 1866, which laid down the basic principles of the rational use of shared water resources. The Water Law of 1866 was never passed due to the revolutionary period that resulted in the First Republic. However, the subsequent Water Law of 1879 included almost all the basic principles of the first one. Spanish water bodies (rivers, lakes and streams) are grouped by river basins, with regulatory agencies, the Hydrographic Confederations, created in the early 20th century [41]. The first Spanish hydrographic confederation was the Hydrographic Confederation of the Ebro, created in 1926. In 1926, this Hydrographic Confederation was named Confederación Sindical Hidrográfica del Ebro; its name was later modified to its present title [42]. Geographically, the Ebro River basin is the largest in Spain, representing 17.3\% of the national territory and covering the area of nine autonomous communities. Due to its extension, the climate in the basin is not at all homogeneous, which is reflected in parameters such as rainfall, temperature, wind and water balance $[43,44]$.

The Ebro River basin makes the largest water contribution of all the basins to the country's electricity generation, considering all the generating technologies, including hydroelectricity. The use of water for hydropower generation has been analyzed [45]. However, the volume of water needed for thermoelectricity has been overlooked in the literature. Looking just at thermoelectricity, there are eight conventional thermal and nuclear power plants operating in the Ebro River basin, the first dating from the 1950s. There are isolated cases of thermal power stations prior to 1950, but they had a very local characters as they were dedicated to supplying electricity to mining installations and villages. This is the case for the Utrillas and Ariño thermoelectric power plants in Aragon (See [46], pp. 240-248). Figure 1 shows the locations of the thermoelectric plants (conventional and nuclear) in the basin. The great variety of generation technologies, and different cooling systems, installed in the facilities make the Ebro River basin especially appropriate for assessing the freshwater needs of thermoelectric power generation.

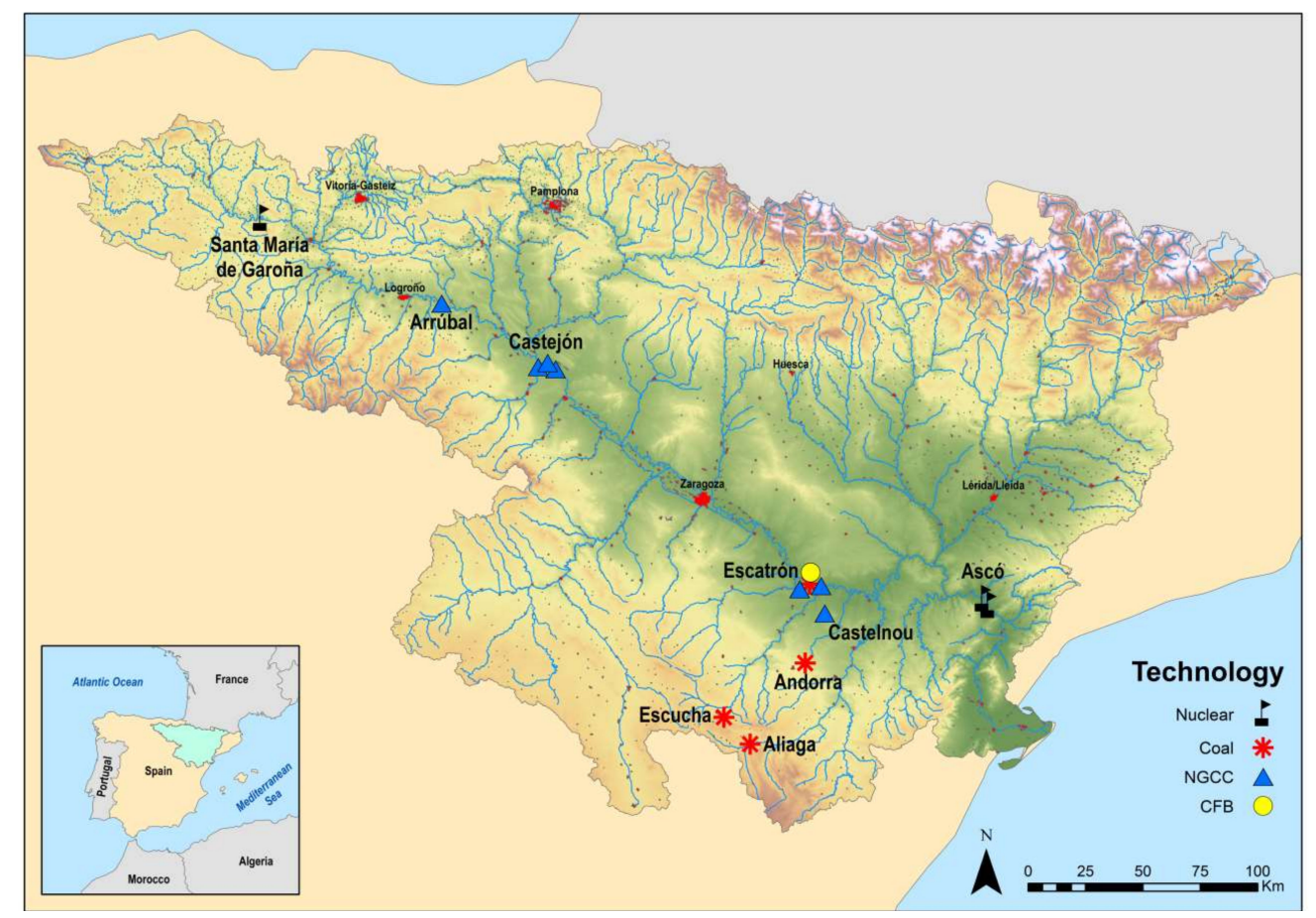

Figure 1. Thermoelectric power plants in the Ebro River basin by type of technology, 1950-2017. Note: NGCC $=$ Natural Gas Combined-Cycle; CFB = Circulating Fluidized Bed. Source: own design using data from the Ebro Hydrographic Confederation and the Spanish National Geographic Institute. 
Approximately $15 \%$ (22,131,246 megawatt hours) of the total thermoelectricity generation in Spain uses water passing through the Ebro River basin. This percentage was even higher some years ago, prior to the closure of the Garoña nuclear power plant and the low output of the combined-cycle power plants in the region from 2010 onwards. In fact, thermoelectric generation in the Ebro River basin multiplied almost 30 times from 1969 to 2000 (from 988,554 to 28,886,000 megawatt hours), and represented more than 20 percent of national thermoelectric generation in the 1980s (Figure 2). Thermal power generation in the river basin reached its historical record in 1985, when it provided more than $25 \%$ of domestic thermoelectric production. Until 1969, only coal plants used the river for thermoelectric production. Then, a nuclear power plant, Garoña, was connected to the grid, followed by two more in Ascó, which meant an increase in water needs for cooling. Finally, in the early 2000s, the first combined-cycle power plants began operation, which again raised water needs. Thus, at its maximum, in 2008, twelve thermal power plants (coal, gas, and uranium), producing around $39 \mathrm{TWh}$, depended on Ebro River water (Figure 3). The Ebro River basin is crucial to Spanish electricity generation, which, in turn, underlines the importance of water as an energy resource in this territory.

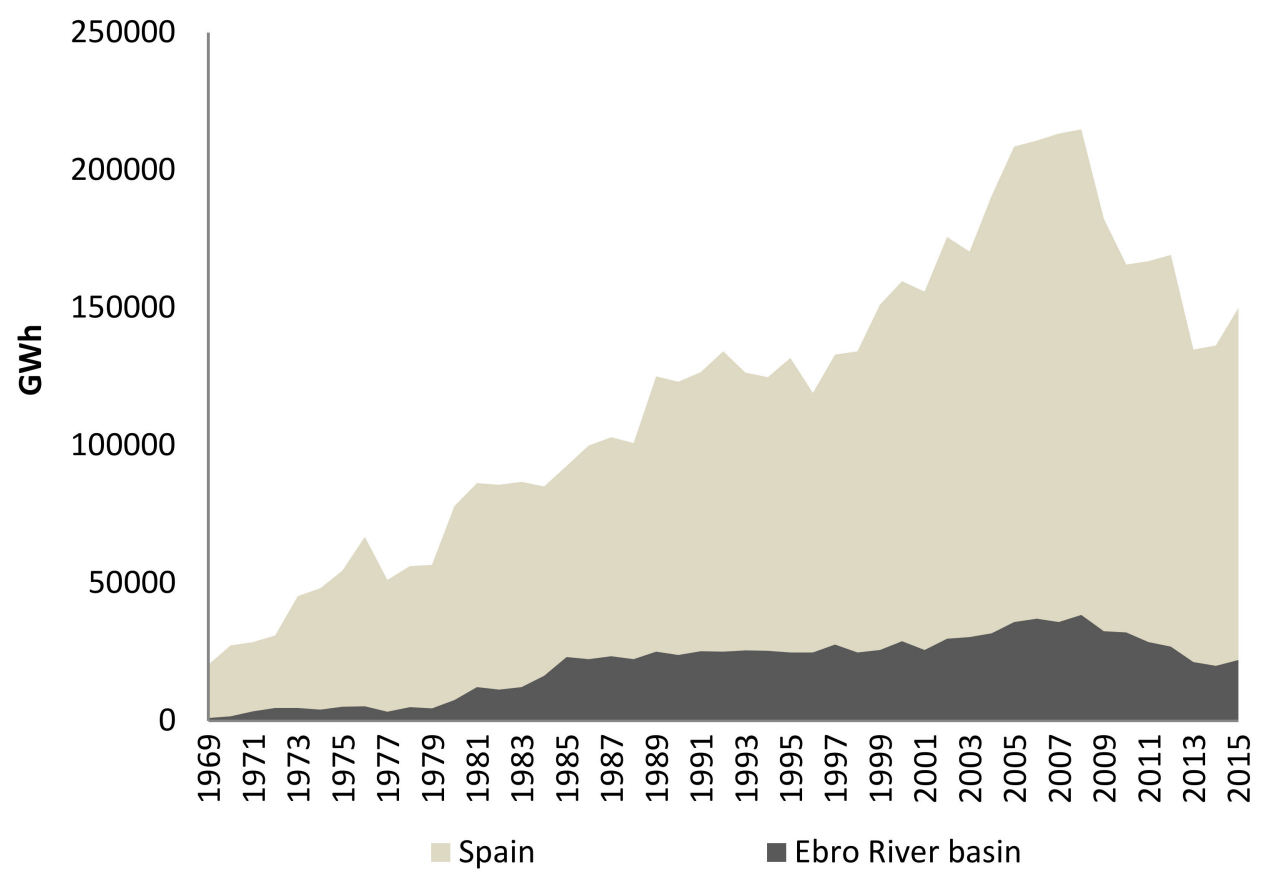

Figure 2. Evolution of thermal power generation in the Ebro River basin within the Spanish thermal power generation system, 1969-2015. Source: own design using data from Spanish Association of Electrical Industry (UNESA) and Red Eléctrica de España (REE). 


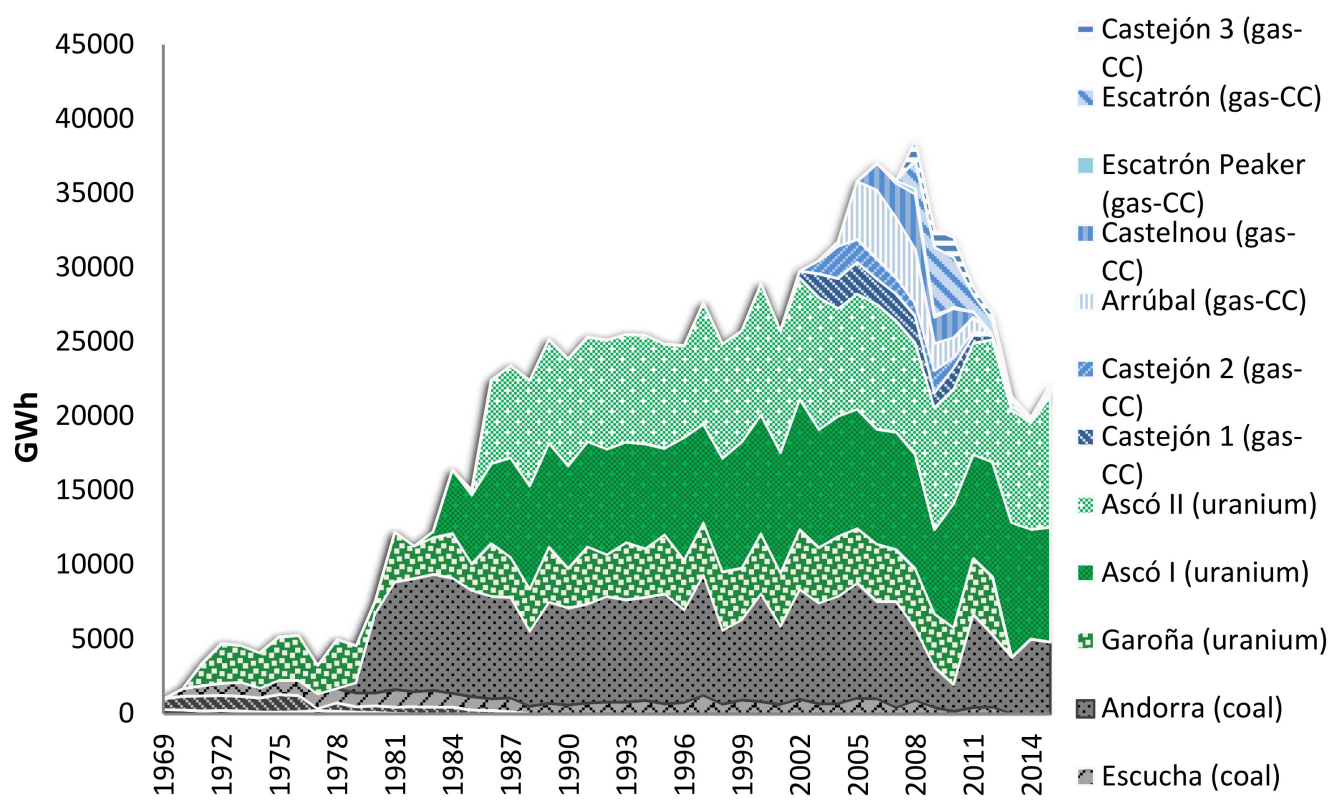

Figure 3. Evolution of thermal power generation by power plant and technology in the Ebro River basin, 1969-2015. Source: own design using UNESA's and REE's annual reports.

\section{Materials and Methods}

\subsection{Water Needs for Cooling}

The thermoelectric power plants withdrawing fresh water in the Ebro River basin during the period 1969-2015 are identified, classified by type of fossil fuel and cooling system (Table 1). Historical and technical information about the Escatrón, Escucha and Teruel thermoelectric power stations is at [46]. Similarly, technical information on the Castejón combined cycle thermal power plant can be found in the environmental impact study published in 2003 by ELEREBRO (now EDP HC Energía). The complete report can be found at [47]. Furthermore, the Spanish Ministry of Industry and Energy published a document on the mining industry in Teruel and Catalonia, which provides technical data from the coal-fired power plants of Andorra, Escucha, and Escatrón. This document can be found at [48]. This classification is crucial, as each thermoelectric technology and cooling system have different water requirements in terms of both withdrawals and consumption.

The thermoelectric power plants in the Ebro River basin work with two cooling technologies: once-through (or open-loop) systems and cooling towers. However, some thermoelectric power stations located in areas of high water stress use air-cooled systems (or dry-recirculating cooling systems) as an alternative, to reduce water demands. These plants, operating with air-cooled condensers (Escucha and Castelnou), are omitted from this analysis, as their cooling systems need little or no water to operate.

To calculate water needs for thermal power generation, it is necessary to obtain data on electricity generation and water intensity factors (both water withdrawals and consumption). Concerning electricity generation, the annual energy output data for the thermal power facilities comes from the UNESA (Spanish Association of Electrical Industry) and REE (Red Eléctrica de España) annual reports for the period 1969-2015. The data on the water-energy nexus in Spain are still limited and, in many cases, the various sources of information are inconsistent [40]. An extensive search provided, in some cases, data from primary sources and from the environmental reports of the electricity companies for most of the power plants currently operating. In other cases, the international literature has provided some information on technical water factors, but it has been impossible to obtain more extensive data (see Table 2). There is a vast body of international literature on the calculation of technical water 
coefficients for the various types of power generation and cooling technologies. One of the first comprehensive references is [49], although since then many others have emerged [50-52].

Table 1. Classification of thermoelectric power plants located in the Ebro River basin by type of technology and cooling system.

\begin{tabular}{|c|c|c|c|c|c|}
\hline Power Plant & Technology & $\begin{array}{l}\text { Installed Power } \\
\text { Capacity (MW) }\end{array}$ & Cooling System & Water Supply & Operation \\
\hline Aliaga & Coal & 45 & Cooling towers & $\begin{array}{c}\text { Guadalope and } \\
\text { Val Rivers }\end{array}$ & (1952-1981) \\
\hline Escatrón & Coal & 172.5 & Once-through & Ebro River & (1953-1987) \\
\hline Escucha & Coal & 160 & $\begin{array}{l}\text { Air-cooled } \\
\text { condensers }\end{array}$ & - & (1970-2012) \\
\hline Andorra & Coal & 1101.4 & Cooling towers & Calanda Dam & (1979-present) \\
\hline Garoña & Nuclear & 466 & Once-through & $\begin{array}{l}\text { Sobrón } \\
\text { Reservoir }\end{array}$ & (1971-2012) \\
\hline Ascó I & Nuclear & 1032.5 & Cooling tower & Ebro River & (1984-present) \\
\hline Ascó II & Nuclear & 1027.21 & Cooling tower & Ebro River & (1986-present) \\
\hline Escatrón & NGCC & 818 & Cooling towers & Ebro River & (2008-present) \\
\hline $\begin{array}{l}\text { Escatrón } \\
\text { Peaker }\end{array}$ & NGCC & 277 & Cooling towers & $\begin{array}{l}\text { Mequinenza } \\
\text { Dam }\end{array}$ & (2007-present) \\
\hline Castelnou & NGCC & 800 & $\begin{array}{l}\text { Air-cooled } \\
\text { condensers }\end{array}$ & - & (2006-present) \\
\hline Arrúbal & NGCC & 800 & Cooling towers & Ebro River & (2005-present) \\
\hline Castejón 1 & NGCC & 429.24 & Cooling towers & Ebro River & (2002-present) \\
\hline Castejón 2 & NGCC & 386.10 & Cooling towers & Ebro River & (2003-present) \\
\hline Castejón 3 & NGCC & 426.11 & Cooling towers & Ebro River & (2008-present) \\
\hline
\end{tabular}

Note: NGCC = Natural Gas Combined Cycle. Source: own design using data from UNESA's and REE's annual reports, BOE, technical reports of the electricity companies, Spanish Nuclear Forum, and Spanish Nuclear Security Council.

Table 2. Average water use factors for thermal power plants by type of technology and cooling system in the Ebro River basin.

\begin{tabular}{|c|c|c|c|c|c|c|}
\hline Power Plant & Technology & $\begin{array}{l}\text { Cooling } \\
\text { System }\end{array}$ & $\begin{array}{l}\text { Withdrawal } \\
\left(\mathrm{m}^{3} / \mathrm{MWh}\right)\end{array}$ & Source & $\begin{array}{l}\text { Consumption } \\
\left(\mathrm{m}^{3} / \mathrm{MWh}\right)\end{array}$ & Source \\
\hline Aliaga & \multirow{3}{*}{ Coal } & $\begin{array}{l}\text { Cooling } \\
\text { tower }\end{array}$ & 3.80 & (a) & 2.60 & (a) \\
\hline Andorra & & $\begin{array}{l}\text { Cooling } \\
\text { tower }\end{array}$ & 2.31 & (b), (c) & 1.11 & (b), (c) \\
\hline Escatrón & & Once-through & 137.60 & (a) & 0.95 & (a) \\
\hline Castejón 1 & \multirow{6}{*}{ NGCC } & $\begin{array}{l}\text { Cooling } \\
\text { tower }\end{array}$ & 1.35 & (b), (c) & 0.97 & (b), (c) \\
\hline Castejón 2 & & $\begin{array}{l}\text { Cooling } \\
\text { tower }\end{array}$ & 1.72 & (b), (c) & 0.97 & (b), (c) \\
\hline Castejón 3 & & $\begin{array}{l}\text { Cooling } \\
\text { tower }\end{array}$ & 1.50 & (b), (c) & 1.00 & (b), (c) \\
\hline Arrúbal & & $\begin{array}{l}\text { Cooling } \\
\text { tower }\end{array}$ & 1.72 & (b), (c) & 0.57 & (b), (c) \\
\hline $\begin{array}{l}\text { Escatrón } \\
\text { Peaker }\end{array}$ & & $\begin{array}{l}\text { Cooling } \\
\text { tower }\end{array}$ & 0.97 & (a) & 0.78 & (a) \\
\hline Escatrón & & $\begin{array}{l}\text { Cooling } \\
\text { tower }\end{array}$ & 0.97 & (a) & 0.78 & (a) \\
\hline $\begin{array}{l}\text { Ascó (units } \\
\text { I-II) }\end{array}$ & \multirow[t]{2}{*}{ Nuclear } & $\begin{array}{l}\text { Cooling } \\
\text { tower }\end{array}$ & 103.58 & (b), (c) & $1.04^{*}$ & (b), (c) \\
\hline $\begin{array}{c}\text { Sta. María } \\
\text { Garoña }\end{array}$ & & Once-through & 154.13 & (b), (c) & 1.02 & (a) \\
\hline
\end{tabular}

Notes: NGCC = Natural Gas Combined-Cycle; (a) [50]; (b) Real data; (c) Environmental Report. *This average factor has been estimated on the basis of primary information sources. However, it is questionable as its value is much lower than the literature suggests should be the case. Source: own design using real data, environmental reports and [50]. Appendix A completes the extensive data search. 
The approach followed for performing the analysis in this study is similar to that followed by [39] in calculating the water needs of Spanish nuclear power plants.

The time periods (years) are designated as $t$ and the thermoelectric power stations as $n$. WCF is the amount of water needed to produce a unit of electricity by power plant $n$, while $W W F^{n}$ is the intensity factor for water withdrawals by power plant $n$. Thus, water consumption (WC) by each power plant $n$ in year $t$ can be calculated by multiplying the intensity factor and the electricity generated (EG). A similar process is followed to obtain water withdrawals (WW). The difference between water withdrawal and consumption is return flow. Formally:

$$
W C_{t}^{n}=W C F_{t}^{n} \times E G_{t}^{n}
$$

and

$$
W W_{t}^{n}=W W F_{t}^{n} \times E G_{t}^{n}
$$

Thus, for a given year, the total amounts are:

$$
\text { Total } W C^{n}=\sum^{n}\left(W C F^{n} \times E G^{n}\right)
$$

and

$$
\text { Total } W W^{n}=\sum^{n}\left(W W F^{n} \times E G^{n}\right)
$$

Therefore, this approach differentiates between water consumption and water withdrawals, since not all the water removed by thermoelectric plants evaporates and is lost. It is crucial to consider total withdrawals, as the facilities require large volumes of water to constantly pass through their systems to function properly. Therefore, these volumes of water could represent an opportunity cost for other productive sectors in the river basin (agriculture, domestic and urban uses, among others) under water stress conditions.

\subsection{Scenario Analysis}

To perform the scenario analyses, all the thermoelectric power plants operating in the river basin (including those using air-cooled condensers) were considered. First, it was necessary to obtain the current energy output data and capacity factors for each power plant. These data allowed the estimation of the maximum attainable energy output. When this maximum output was obtained, the maximum water withdrawals and consumption (in other words, the maximum water needs of a power plant operating at $100 \%$ of capacity) could be calculated by multiplying the maximum energy output and the corresponding average technical water coefficient (see Table 2). Finally, after analyzing all possible combinations that satisfy the restrictions imposed (namely, the maximum nuclear output), the best combinations could be chosen for each scenario.

\section{Results}

Applying Formulas (3) and (4) we see that total water withdrawals and consumption in the basin follow the same trend as thermoelectricity production over time (see Figure 3). Thus, whereas water withdrawals range from 100 to $2600 \mathrm{hm}^{3}$ cubic hectometers over the period, reaching peak volumes in 2003, water consumption ranges through a minor order of magnitude (i.e., from 1.3 to $33 \mathrm{hm}^{3}$ ). The greatest increases took place in the 1980s, mainly due to the beginning of operations at the Ascó nuclear power plant. More specifically, Figure 4a,b drill further down and show the share of water withdrawals and consumption by generation technology over time. Figure 4a indicates that most water withdrawals were due to the operation of the nuclear power plants (more than $60 \%$ from 1971). By contrast, water withdrawals from coal-fired power plants were important only in the first half of the period, and water withdrawals from combined-cycle power stations are almost non-existent 
compared to the other generating technologies. There are two explanations for this. On the one hand, combined-cycle power plants use less water (see Table 2), and on the other, many of the plants were under-utilized due to low electricity demand after 2012. Figure $4 \mathrm{~b}$ shows that, from the 2000s, nuclear once again consumed the most water, followed by coal and natural gas combined-cycle technology.

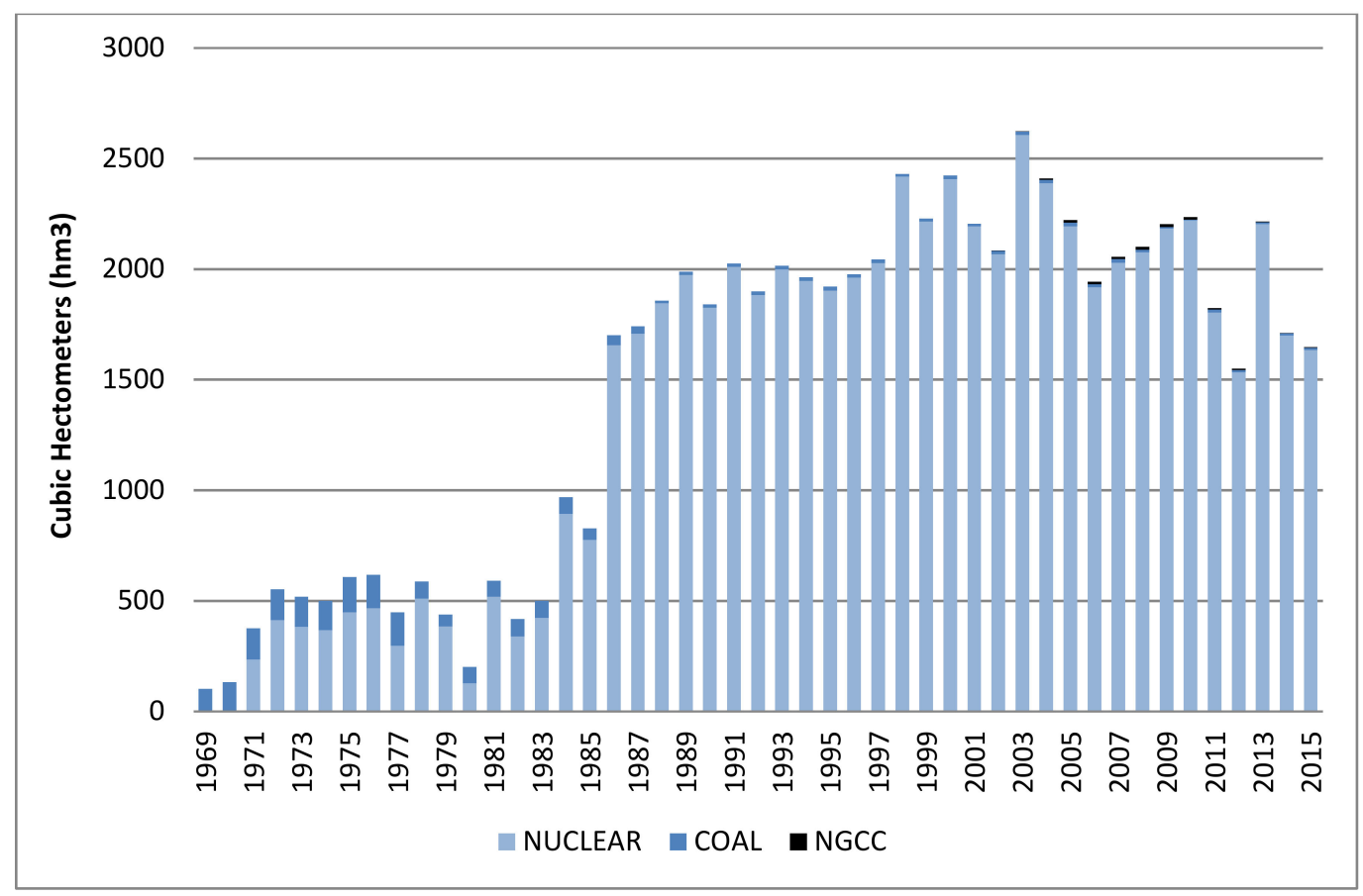

(a)

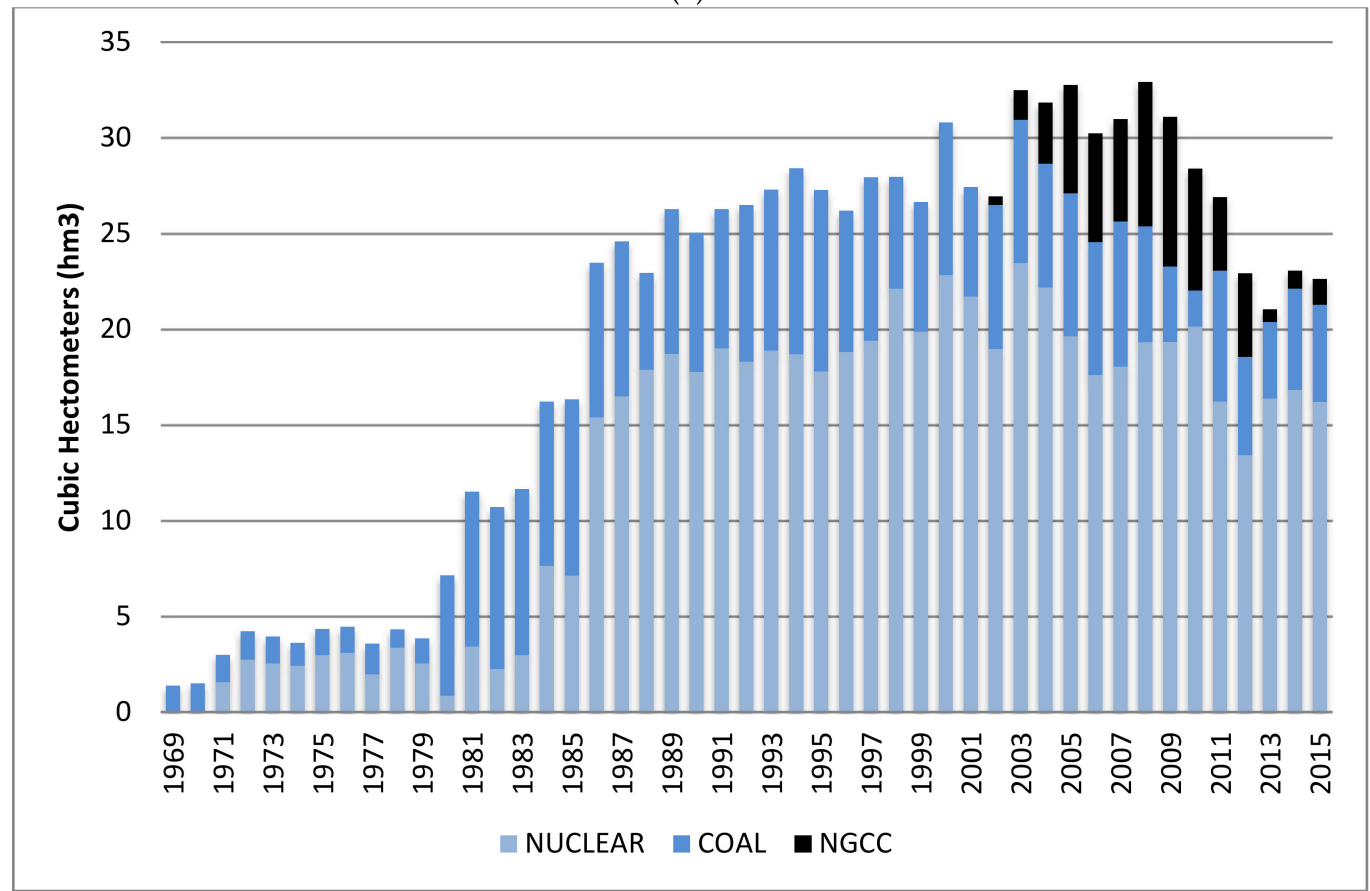

(b)

Figure 4. (a) Evolution of total water withdrawals by type of technology in the Ebro River basin, 1969-2015. Source: own design (see 'Data File S1' in Supplementary Materials). (b) Evolution of total water consumption by type of technology in the Ebro River basin,1969-2015. Source: own design (see 'Data File S1' in Supplementary Materials). 
The population of the Ebro River basin is around 3.2 million, i.e., 37 inhabitants per square kilometer [53]. The blue water footprint per capita (the result of dividing water consumption from thermal power plants by population) oscillated around $7 \mathrm{~m}^{3}$ /year between 2013 and 2015. The Ebro Hydrographical Confederation provides data on the theoretical demands and consumption of the most important productive sectors in the basin (Table 3), which, interestingly, excludes the thermoelectricity sector. Thus, a sectoral comparison can be made between the above results and the other economic activities to rank the different uses of water in the region.

Table 3. Comparison between water withdrawals and consumption by type of productive activity in the Ebro River basin, 2010-2015.

\begin{tabular}{ccc}
\hline Productive Activity & Withdrawals $\mathbf{~ h m ~}^{\mathbf{3}}$ /year) & Consumption (hm $\mathbf{~}^{\mathbf{3}} /$ year) \\
\hline Agricultural uses & 7681 & 4574 \\
Water for thermoelectricity (this study) & $1550-2234$ & $22-28$ \\
Urban water supply & 358 & 71 \\
Industrial uses (excluding power sector) & 147 & 29 \\
Livestock & 57 & 11 \\
\hline
\end{tabular}

Source: For thermoelectricity requirements, see text. All other figures are theoretical amounts taken from the Ebro Hydrographic Confederation website [53].

According to these figures, water removals for thermal power generation in the basin moved between 1550 and $2234 \mathrm{hm}^{3}$ during 2010-2015. Thus, the thermoelectric power sector is the second thirstiest in the basin, just behind agriculture. Conversely, water consumption from thermal power stations reached $28 \mathrm{hm}^{3}$ in the same period. Thus, the thermoelectric power sector ranks fourth, almost equaling industrial use.

The measurement of the evolution of water intensity (i.e., the cubic meters needed to produce $1 \mathrm{MWh}$ ) in thermal power stations may be a useful political tool with which to argue for more rational use of water for cooling in the Ebro River basin. This metric, known as 'technological water intensity' in the international literature, is defined as the measure of the overall efficiency of water consumption (or withdrawal) for energy production [54]. Thus, increases in the ratio $\left(\frac{\mathrm{m}^{3}}{\mathrm{MWh}}\right)$ lead to a loss of water efficiency, as more cubic meters are needed to generate a unit of electricity, and vice versa. Figure 5 shows a general downward trend in terms of withdrawals and consumption. Specifically, the ratio for water withdrawals rose between 1969 and 1972, reached its peak in 1975 (around $145 \mathrm{~m}^{3} / \mathrm{MWh}$ ), and remained stagnant until 1979. Thereafter, from 1980, the ratio plummeted to its lowest value $\left(29 \mathrm{~m}^{3} / \mathrm{MWh}\right)$. This major drop is explained by the commissioning of the Andorra coal-fired power plant, with its 1101.4 MW of installed power and cooling towers, which involved a substantial increase in thermoelectric production and very limited water withdrawals due to its cooling system. The ratio increased again in the 1980's, due to the beginning of operations at the Ascó nuclear power plant, which caused higher volumes of water withdrawals (see Table 2 above). From that point, the ratio fluctuated, but remained below $105 \mathrm{~m}^{3} / \mathrm{MWh}$. By contrast, the water consumption ratio fluctuated little, and around much lower values (i.e., between 0.8 and $1.4 \mathrm{~m}^{3} / \mathrm{MWh}$ ), as expected. However, in some cases, the understanding of this ratio may not be as simple as mentioned above. For example, regional electricity demand can increase or decrease, such that factors affecting the ratio may lead to an overall increase or decrease in water requirements. 


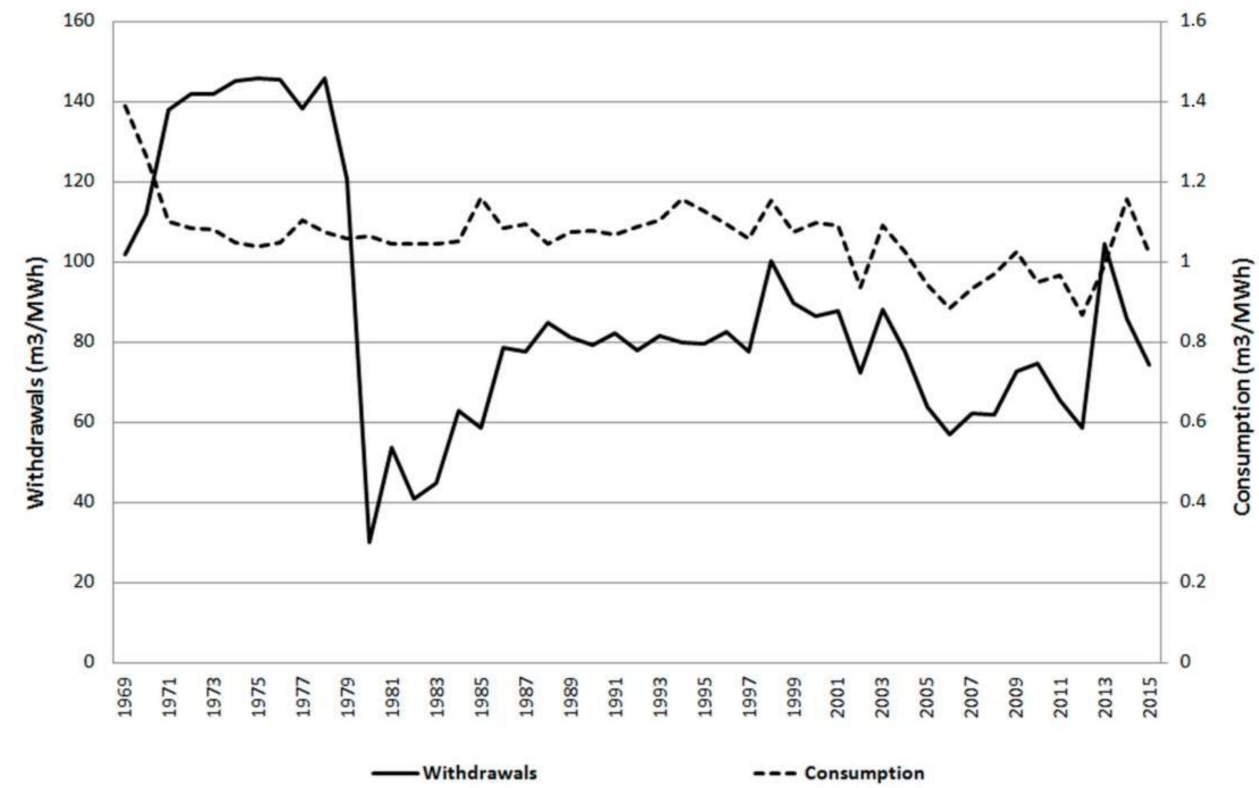

Figure 5. Evolution of technological water intensity in terms of water withdrawals (left axis) and water consumption (right axis) of thermal power stations in the Ebro River basin, 1969-2015. Note: The Escucha and Castelnou coal-fired power stations-using air-cooled condensers-are excluded. Source: own design (see 'Data File S1' in Supplementary Materials).

These results suggest that substantial water savings could be achieved by shutting down the two generation units of the Ascó nuclear power plant, although their electrical power would have to be supplied by other types of plants (e.g., coal or natural gas combined-cycle power stations). Given that some combined-cycle plants in the Ebro River basin are under-utilized, a reasonable option would be to determine whether these plants, working at maximum power, could replace the output of the Ascó nuclear power plant. For this purpose, the maximum output, water withdrawals and water consumption have been estimated on the basis of actual output data, the capacity factors and the technical water coefficients of each thermal power plant operating (see Table 4).

Table 4. Estimation of the maximum output, water withdrawals and water consumption attainable by the thermal power plants of the Ebro River basin.

\begin{tabular}{|c|c|c|c|c|c|}
\hline Power Plant & $\begin{array}{l}\text { Actual Output } \\
\text { (GWh) }\end{array}$ & $\begin{array}{c}\text { (1) Capacity } \\
\text { Factor }(\%)\end{array}$ & $\begin{array}{l}\text { Maximum Output } \\
\text { (GWh) Estimated } \\
\text { from (1) }\end{array}$ & $\begin{array}{c}\text { Maximum Water } \\
\text { Withdrawals } \\
\left(\mathrm{hm}^{3}\right)\end{array}$ & $\begin{array}{l}\text { Maximum Water } \\
\text { Consumption } \\
\left(\mathrm{hm}^{3}\right)\end{array}$ \\
\hline Ascó (all units) & 15,850 & 97.6 & 16,240 & 1682 & 16.9 \\
\hline Andorra (all units) & 4,459 & 49.1 & 9082 & 21 & 10 \\
\hline Castejón 1 & 337 & 9.3 & 3623 & 4.9 & 3.5 \\
\hline Castejón 2 & 7 & 0.2 & 3500 & 6 & 3.4 \\
\hline Castejón 3 & 387 & 10.6 & 3650 & 5.5 & 3.7 \\
\hline Arrúbal (all units) & 163 & 2.4 & 6795 & 11.7 & 3.9 \\
\hline EscatrónPeaker & 27 & 1.1 & 2454 & 2.4 & 1.2 \\
\hline Escatrón & 65 & 0.9 & 7222 & 7 & 5.6 \\
\hline Castelnou * & 86 & 1.3 & 6615 & 0 & 0 \\
\hline
\end{tabular}

Notes: The data refer to figures for year 2015, except for Castejón 2 and the two generation units of the Arrúbal combined-cycle power plant, which show data for 2013 and 2014, respectively. Due to low electricity demand, the production of these plants in later years was zero. The Aliaga and Escatrón coal-fired power stations and the Garoña nuclear power plant have been omitted; they have already been dismantled. * This power plant is cooled via air-condensers and its water requirements are zero or almost zero. Therefore, a technical water coefficient of zero has been applied. (1) This is the ratio between actual production and possible or maximum production that the plant could reach operating at nominal power. Source: own design based on the reports of the Spanish Electricity System published by Red Eléctrica de España (REE).

Table 4 shows that, although the two generation units of the Ascó nuclear power plant are operating at almost their maximum (i.e., utilization ratios very close to $100 \%$ ), the Andorra coal-fired 
power station is barely reaching $50 \%$ of its maximum. As previously mentioned, the other power plants (the combined-cycle power stations) are under-utilized, with ratios close to $10 \%$ and even lower. The maximum output of the Ascó nuclear power plant is around 16,240 GWh. Thus, different scenarios could come into play if the other thermal power plants began to operate at full capacity to replace nuclear production; we may face a future without nuclear power plants. These scenarios are detailed below.

Scenario 1. A mix of coal-fired and combined-cycle power plants (without Castelnou).

This scenario covers the three best combinations of coal-fired and combined-cycle power plants (see Table 5) which, operating at maximum capacity, can reach an output equal to or greater than 16,240 GWh, while consuming little water. Therefore, this set of power plants would be enough to cover predicted electricity supply if the existing nuclear power plants in the Ebro River basin closed down.

Table 5. Set of combinations from Scenario 1.

\begin{tabular}{cccc}
\hline Power Plants & $\begin{array}{c}\text { Maximum Output } \\
(\mathbf{G W h})\end{array}$ & $\begin{array}{c}\text { Maximum Water } \\
\text { Withdrawal }\left(\mathbf{h m}^{\mathbf{3}}\right)\end{array}$ & $\begin{array}{c}\text { Maximum Water } \\
\text { Consumption }\left(\mathbf{h m}^{\mathbf{3}}\right)\end{array}$ \\
\hline C.1 (Andorra, Escatrón) & 16,304 & 28 & 15.7 \\
C.2 (Andorra, Castejón 1, Castejón 3) & 16,357 & 31.4 & 17.2 \\
C.3 (Andorra, Arrúbal, Escatrón Peaker) & 18,332 & 35 & 15.9 \\
\hline
\end{tabular}

The water withdrawal combinations possible in this scenario use around $2 \%$ of the water withdrawals from nuclear power plants $\left(1682 \mathrm{hm}^{3}\right)$. By contrast, water consumption is over $90 \%$ in the three cases analyzed. Furthermore, the second combination of power plants (i.e., Andorra, Castejón 1, and Castejón 3) is particularly important; water consumption here slightly exceeds that of the Ascó nuclear power plants (17.2 versus $16.9 \mathrm{hm}^{3}$ ).

Scenario 2. A mix of coal-fired and combined-cycle power plants (with Castelnou)

More water-saving combinations are possible based on the water requirements of each cooling system. The Castelnou combined-cycle power plant (with a maximum output very similar to that of the Escatrón and Arrúbal power stations) cools through air-condensers and, hence, its water requirements are almost zero. Therefore, this scenario (see Table 6) is a much better alternative in terms of both water withdrawal and consumption than Scenario 1. For example, while water withdrawal ranges from 23 to $27 \mathrm{hm}^{3}$, water consumption revolves around $13 \mathrm{hm}^{3}$. Thus, savings in water withdrawal from thermal power stations in this scenario are around 98\%, while savings in water consumption are around $20-30 \%$ (See Figure 5 below).

Table 6. Set of combinations in Scenario 2.

\begin{tabular}{|c|c|c|c|}
\hline Power Plants & $\begin{array}{l}\text { Maximum Output } \\
\text { (GWh) }\end{array}$ & $\begin{array}{l}\text { Maximum Water } \\
\text { Withdrawal }\left(\mathrm{hm}^{3}\right)\end{array}$ & $\begin{array}{c}\text { Maximum Water } \\
\text { Consumption }\left(\mathrm{hm}^{3}\right)\end{array}$ \\
\hline $\begin{array}{c}\text { C.1 (Andorra, Escatrón Peaker, } \\
\text { Castelnou) }\end{array}$ & 18,152 & 23.3 & 12 \\
\hline C.2 (Andorra, Castejón 2, Castelnou) & 19,198 & 27 & 13.4 \\
\hline C.3 (Andorra, Castejón 1, Castelnou) & 19,321 & 25.9 & 13.6 \\
\hline
\end{tabular}

Scenario 3. A setup consisting solely of combined-cycle power plants (without Castelnou).

An even more efficient scenario would use only combined-cycle power plants (Table 7), which are much more water-saving than coal-fired plants (see Table 2). Electricity production of $16,240 \mathrm{GWh}$ could be achieved using less water than the two previous scenarios. Water withdrawals would account for only $1 \%$ and water consumption around $70 \%$ of nuclear power plants. In other words, water savings achieved in this scenario are around $99 \%$ and 30\% respectively (see Figure 6). 
Table 7. Set of combinations in Scenario 3.

\begin{tabular}{|c|c|c|c|}
\hline Power Plants & $\begin{array}{l}\text { Maximum Output } \\
\text { (GWh) }\end{array}$ & $\begin{array}{c}\text { Maximum Water } \\
\text { Withdrawal }\left(\mathrm{hm}^{3}\right)\end{array}$ & $\begin{array}{c}\text { Maximum Water } \\
\text { Consumption }\left(\mathrm{hm}^{3}\right)\end{array}$ \\
\hline $\begin{array}{c}\text { C.1 (Castejón 1, Castejón 2, Arrúbal, } \\
\text { Escatrón Peaker) }\end{array}$ & 16,373 & 25 & 12.7 \\
\hline $\begin{array}{c}\text { C.2 (Castejón 2, Castejón 3, Arrúbal, } \\
\text { Escatrón Peaker) }\end{array}$ & 16,400 & 25.6 & 12.8 \\
\hline C.3 (Arrúbal, Escatrón Peaker, Escatrón) & 16,472 & 21 & 11.4 \\
\hline
\end{tabular}

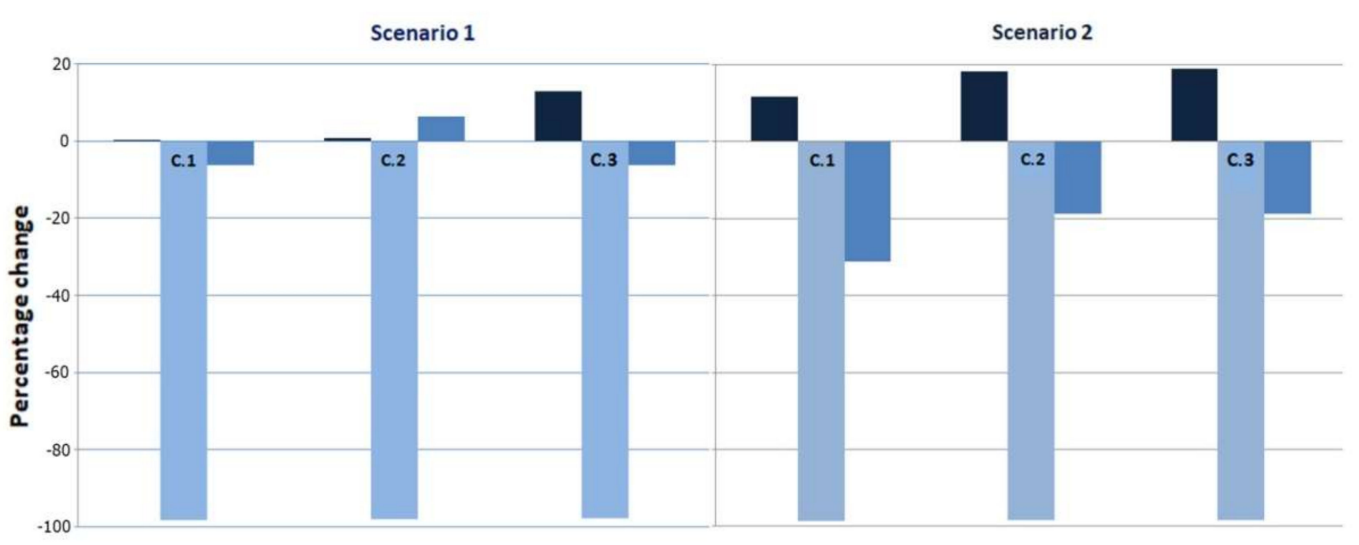

Selected combinations

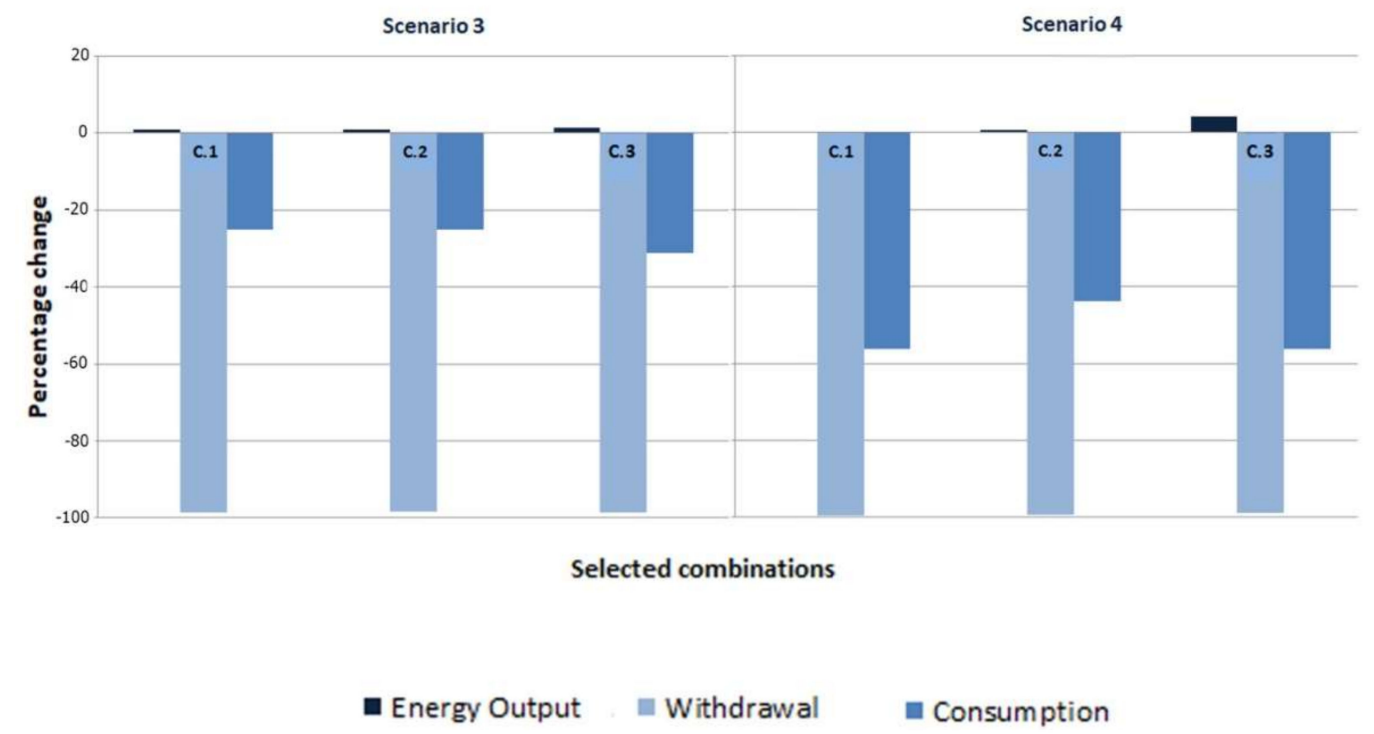

Figure 6. Summary of scenarios compared to the baseline. Note: the maximum output, water withdrawals, and water consumption attainable by nuclear power plants represent the baseline. Values above zero show increases in energy output or water use compared to the baseline. Values below zero show water savings compared to the baseline. Source: own design.

Scenario 4. A setup consisting solely of combined-cycle power plants (with Castelnou).

The Castelnou thermal power plant would, again, guarantee additional water savings, due to its air-cooling system. Therefore, the combinations below (see Table 8) represent the best water-saving options. In this scenario, combinations of water withdrawals are around $1 \%$ of withdrawals from nuclear power plants, and water consumption is between $40-50 \%$ of nuclear power stations (around $7-9 \mathrm{hm}^{3}$ compared to $16.9 \mathrm{hm}^{3}$ ). 
Table 8. Set of combinations in Scenario 4.

\begin{tabular}{cccc}
\hline Power Plants & $\begin{array}{c}\text { Maximum Output } \\
(\mathbf{G W h})\end{array}$ & $\begin{array}{c}\text { Maximum Water } \\
\text { Withdrawal }\left(\mathbf{h m}^{3}\right)\end{array}$ & $\begin{array}{c}\text { Maximum Water } \\
\text { Consumption }\left(\mathbf{h m}^{3}\right)\end{array}$ \\
\hline C.1 (Escatrón Peaker, Escatrón, & 16,292 & 9.4 & 7.5 \\
$\begin{array}{c}\text { Castelnou) } \\
\text { C.2 (Castejón 1, Castejón 3, Escatrón }\end{array}$ & 16,344 & 12.7 & 9 \\
$\begin{array}{c}\text { Peaker, Castelnou) } \\
\text { C.3 (Castejón 2, Arrúbal, Castelnou) }\end{array}$ & 16,910 & 17.7 & 7.3 \\
\hline
\end{tabular}

The scenarios presented above do not refer to any particular time horizon. The scenarios merely aim to demonstrate that it is possible to produce almost similar energy outputs while saving large amounts of water under a hypothetical future without nuclear power plants in the Ebro river basin. However, these water savings would be achieved at the expense of higher $\mathrm{CO}_{2}$ emissions. Likewise, the estimated maximum water withdrawals (See Table 4) would satisfy the concessions originally imposed by the Ebro Hydrographic Confederation, except for the Andorra thermal power station. This thermal power plant would exceed $2 \mathrm{hm}^{3}$-its original concession.

\section{Discussion}

This article quantifies the volume of water used in the cooling processes of the thermoelectric plants in the Ebro River basin. However, issues related to the qualitative aspects of water have been largely set aside. The increase in river temperatures is attracting the most research attention $[55,56]$. For example, increases in river temperatures due to climate change might affect the cooling capacity of conventional and nuclear power plants. In other words, high temperatures might force the plants to reduce their capacity due to the decrease in cooling flow. At the same time, water discharges from thermal power stations could also pose a risk to the environment by increasing water temperatures and affecting water ecosystems. These issues will need future research: the assessment of qualitative impacts on water requires different research strategies.

There are geographical differences within the river basin; the distribution of freshwater resources among competing users is already posing a problem in specific areas with water scarcity problems. Thus, according the Hydrological Plan of the Ebro Hydrographic Demarcation 2015-2021 (for the complete Hydrological Plan, see [57]), water scarcity in the area of the Andorra coal-fired power, with its demand of $18 \mathrm{hm}^{3} /$ year, has required agreements to be reached to balance the needs of energy and irrigation. Therefore, future research on this matter at a lower level of disaggregation could be interesting, given the geographical differences within the Ebro River basin itself.

The collection of real data for most power plants has made it possible to carry out a comparative analysis in terms of water factors among the facilities, different types of technologies, and cooling systems (see Table 2). Thermal generating technology nuclear power plants require the greatest water withdrawals and consumption. Similarly, open-loop systems require greater water withdrawals, and cooling towers entail higher water consumption (i.e., water evaporation losses). In this regard, the data on the water consumption of the Ascó nuclear power plant seems very questionable if compared to the technical water factors discussed in the international literature for the same type of technologies and cooling systems. Therefore, although real data are available for this nuclear power plant, this water consumption factor should probably be greater to be in line with other research. Finally, this refinement of the database has led to a substantial improvement in the results related to Spanish nuclear power plants published in previous studies [39]. Thus, this study confirms that water cooling demands in the Ebro River basin do not exceed the maximum threshold stipulated by the Ebro Hydrographic Confederation in its original concessions (i.e., $3340 \mathrm{hm}^{3}$ ).

As mentioned previously, thermoelectric generation in the Ebro River basin multiplied almost 30 times from 1969 to 2000. The results show that, during the period, water withdrawals and water consumption multiplied approximately 24 and 22 times, respectively, which suggests some efficiency in water use. More extensive analysis on technological water intensity was carried out for the period. 
Thus, the improvement of existing cooling systems or, even the replacement of cooling systems that have high water demands by lower demand systems, could be alternatives if additional reductions in the demand for water are necessary. In any case, the demand for water for cooling is not expected to significantly increase in the Ebro River basin in the short term. According to the last Hydrological Plan for 2015-2021, there is little likelihood that new coal-fired power plants will be installed in the Ebro River basin in the coming years, as this would be limited by $\mathrm{CO}_{2}$ capture and storage technologies, the development of $\mathrm{CO}_{2}$ transport, and the establishment of gas storage facilities. Similarly, no more nuclear power plants will be installed in the river basin, mainly due to the low acceptance of nuclear energy by the Spanish population. Lastly, the installation of new combined-cycles plants in the region is unlikely due to low electricity demands and the underutilization of existing combined-cycle plants. Therefore, water concessions for cooling are unlikely to increase in the near future and, therefore, neither will water consumption.

To sum up, these findings contribute to a better understanding of the energy-water nexus in Spain, the most arid country in Europe. However, detailed data about thermal power facilities' water withdrawals and consumption are still barely accessible. This creates significant difficulties in assessing the water-energy nexus and in making integrated decisions in the water and energy sectors. Therefore, advances in the publication of public and open data in Spanish official information sources will be necessary to improve research in this area. This is demonstrated by research on the lack of open data on water use and the inconsistencies among the different information sources on the Spanish water-energy nexus $[40,58]$.

\section{Conclusions}

This study estimates the water needs for thermoelectric power generation in the Ebro River basin through an analysis based on the calculation of technical water factors. The difference between water withdrawals and consumption is considerable. Thus, although the value of thermoelectric water consumption seems to be of little importance, it equals the amount of water taken for industrial use. The quantities of water withdrawals should not be overlooked, as in times of drought, these amounts of water could affect the water demands of the other water users in the basin. This point is reinforced when a sector ranking is carried out. For example, thermoelectricity generation is second in water demand only behind agriculture. Moreover, this paper shows that water intensity in consumption and withdrawals for thermoelectricity has declined slightly over the years. Finally, the results show that similar quantities of electricity can be generated using less water. Given the different water requirements of each type of generation technology and cooling system, significant water savings could be achieved if we face a future without nuclear power plants in the Ebro River basin. More water will be saved by using combinations of natural gas combined-cycle plants, including the Castelnou power plant.

Supplementary Materials: The following are available online at http:/ / www.mdpi.com/2073-4441/11/3/441/s1, Data File S1: water withdrawals, water consumption, and water intensity.

Funding: This research was supported by the Spanish Government through the MINECO research projects, references HAR2014-53825-R and HAR2017-86086-R. The author also benefits from a research contract from Spanish Government through MINECO reference BES-2015-074128.

Acknowledgments: A preliminary version of this paper was presented at different venues, including the International Conference on Regional Science (Sevilla, Spain, November 2017), the 12th European Social Science History Conference (Belfast, North Ireland, April 2018), the Economics Department at Public University of Navarre and the II Jornada Doctoral sobre Ciencia Regional para Investigadores en Formación (University of Zaragoza). I acknowledge the helpful comments and suggestions received. I also appreciate the bibliographical suggestions received from the Centro de Documentación del Agua y del Medio Ambiente de Zaragoza (CDAMAZ). I thank Pedro Duarte for his help in solving my doubts with GIS tools. Special thanks to Mar Rubio-Varas for her support, comments and suggestions for improvement. Finally, I also express my gratitude for the observations of two anonymous reviewers. Their comments led to significant improvements to this paper. The remaining errors are solely mine. 
Conflicts of Interest: The author declares no conflict of interest. The funders had no role in the design of the study; in the collection, analyses, or interpretation of data; in the writing of the manuscript, or in the decision to publish the results.

\section{Appendix A}

The following sources of information complete the extensive data search from Table 2:

ENDESA S.A. environmental reports for Andorra's thermal power station from 2011: available at [59]. IBERDROLA S.A. and EDP HC Energía environmental reports for the Castejón generating units 1, 2, and 3, from 2005 up to now: available at [60,61]. More data on the theoretical water flows rates, removals and consumption of the Castejón combined cycle thermal power plant can be found in the environmental impact study published in 2003 by ELEREBRO (now EDP HC Energía), available at [47].

Periodical publications from the Spanish official gazette and some Autonomous Communities containing water data: BOE 289. 3 December 2002, pp. 42230-42243; BOA 102. 28 May 2013, pp. 11969-11996; BOR 54. 1 May 2003, Section III.B.43; BOE 309. 24 December 2009, Section III, pp. 109653-10967; BOE 101. 27 April 2000, pp. 16395-16412; BOE 129. 31 May 2005, pp. 18317-18329; BOE 136. June 7, 2000, pp. 7596-7597; BOE 248. October 14, 2009, pp. 86859-86883; BOE 244. October 11, 2001, pp. 37509-37519; BOE 240. 7 October 2005, pp. 33034-33047; BOE 284. 25 November 2004, pp. 39076-39089; BOE 49. 26 February 2015, pp. 18618-18623.

The Ebro Hydrographic Confederation [53] presents theoretical maximum volumes of water withdrawals for Ascó $\left(2270 \mathrm{hm}^{3}\right.$ /year), Santa María de Garoña $\left(766 \mathrm{hm}^{3}\right.$ /year), and Teruel conventional power station $\left(18 \mathrm{hm}^{3} /\right.$ year). No figures are given for all those power plants located in Arrúbal, Castejón, and Escatrón.

Theoretical data on water volumes for the Andorra power plant can be seen at [62].

This table shows average factors for water withdrawals and consumption, but the analysis has been carried out using more precise water factors for most power plants, obtained directly from the operators. However, due to confidentiality agreements, the specific factor cannot be shown.

\section{References}

1. IEA (International Energy Agency). Water Energy Nexus. In World Energy Outlook 2016; OECD/IEA: Paris, France, 2016. Available online: https://www.iea.org/publications/freepublications/publication/ WorldEnergyOutlook2016ExcerptWaterEnergyNexus.pdf (accessed on 17 December 2018).

2. Scott, C.A.; Pierce, S.A.; Pasqualetti, M.J.; Jones, A.L.; Montz, B.E.; Hoover, J.H. Policy and institutional dimensions of the water-energy nexus. Energy Policy 2011, 39, 6622-6630. [CrossRef]

3. Hussey, K.; Pittock, J. The Energy-Water Nexus: Managing the Links between Energy and Water for a Sustainable Future. Ecol. Soc. 2012, 17, 31. [CrossRef]

4. Ackerman, F.; Fisher, J. Is there a water-energy nexus in electricity generation? Long-term scenarios for the western United States. Energy Policy 2013, 59, 235-241. [CrossRef]

5. Hamiche, A.M.; Stambouli, A.B.; Flazi, S. A review of the water-energy nexus. Renew. Sustain. Energy Rev. 2016, 65, 319-331. [CrossRef]

6. Miglietta, P.; Morrone, D.; De Leo, F. The Water Footprint Assessment of Electricity Production: An Overview of the Economic-Water-Energy Nexus in Italy. Sustainability 2018, 10, 228. [CrossRef]

7. Lofman, D.; Petersen, M.; Bower, A. Water, Energy and Environment Nexus: The California Experience. Int. J. Water Resour. Dev. 2002, 18, 73-85. [CrossRef]

8. Siddiqi, A.; Anadon, L.D. The water-energy nexus in Middle East and North Africa. Energy Policy 2011, 39, 4529-4540. [CrossRef]

9. Stillwell, A.S.; King, C.W.; Webber, M.E.; Duncan, I.J.; Hardberger, A. The energy-water nexus in Texas. Ecol. Soc. 2011, 16, 2. [CrossRef]

10. Scanlon, B.R.; Duncan, I.; Reedy, R.C. Drought and the water-energy nexus in Texas. Environ. Res. Lett. 2013, 8, 045033. [CrossRef] 
11. Erensu, S. Abundance and scarcity amidst the crisis of 'modern water': The changing water-energy nexus in Turkey. In Contemporary Water Governance in the Global South; Routledge: London, UK, 2015; pp. 61-78.

12. Lubega, W.N.; Stillwell, A.S. Maintaining electric grid reliability under hydrologic drought and heat wave conditions. Appl. Energy 2018, 210, 538-549. [CrossRef]

13. Kahrl, F.; Roland-Holst, D. China's water-energy nexus. Water Policy 2008, 10, 51-65. [CrossRef]

14. Eyre, N.; Hall, J.W.; Liao, X. Water for energy in China. In Food, Energy and Water Sustainability; Routledge: London, UK, 2017; pp. 67-87.

15. Zhang, X.; Liu, J.; Tang, Y.; Zhao, X.; Yang, H.; Gerbens-Leenes, P.; Van Vliet, M.T.; Yan, J. China's coal-fired power plants impose pressure on water resources. J. Clean. Prod. 2017, 161, 1171-1179. [CrossRef]

16. Liu, L.; Hejazi, M.; Patel, P.; Kyle, P.; Davies, E.; Zhou, Y.; Clarke, L.; Edmonds, J. Water demands for electricity generation in the U.S.: Modeling different scenarios for the water-energy nexus. Technol. Forecast. Soc. Chang. 2015, 94, 318-334. [CrossRef]

17. Eyer, J.; Wichman, C.J. Does water scarcity shift the electricity generation mix toward fossil fuels? Empirical evidence from the United States. J. Environ. Econ. Manag. 2018, 87, 224-241. [CrossRef]

18. Zhou, Q.; Hanasaki, N.; Fujimori, S.; Yoshikawa, S.; Kanae, S.; Okadera, T. Cooling Water Sufficiency in a Warming World: Projection Using an Integrated Assessment Model and a Global Hydrological Model. Water 2018, 10, 872. [CrossRef]

19. Mazdiyasni, O.; AghaKouchak, A. Substantial increase in concurrent droughts and heatwaves in the United States. Proc. Natl. Acad. Sci. USA 2015, 112, 11484-11489. [CrossRef] [PubMed]

20. Rodriguez, D.J.; Delgado, A.; DeLaquil, P.; Sohns, A. Thirsty energy. In Water Papers; World Bank: Washington, DC, USA, 2013; Available online: https:/ / openknowledge.worldbank.org/handle/10986/16536 (accessed on 18 December 2018).

21. International Energy Agency. World Energy Outlook. Available online: https://www.iea.org/weo (accessed on 18 December 2018).

22. World Bank Group. Thirsty Energy. Available online: http://www.bancomundial.org/es/topic/ sustainabledevelopment/brief/water-energy-nexus (accessed on 18 December 2018).

23. Delgado, A.; Rodríguez, D.J.; Sohns, A.A. Thirsty Energy: Understanding the Linkages between Energy and Water. 2015. Available online: http://documents.worldbank.org/curated/en/944141468329076361/Thirstyenergy-understanding-the-linkages-between-energy-and-water (accessed on 28 February 2019).

24. Glassman, D.; Wucker, M.; Isaacman, T.; Champilou, C. The Water-Energy Nexus: Adding to the Energy Agenda. World Policy Paper; World Policy Institute: New York, NY, USA, 2011. Available online: https: / / worldpolicy.org/2011/03/18/the-water-energy-nexus/ (accessed on 18 December 2018).

25. Bauer, D.; Philbrick, M.; Vallario, B.; Battey, H.; Clement, Z.; Fields, F. The Water-Energy Nexus: Challenges and Opportunities; US Department of Energy: Washington, DC, USA, 2014. Available online: http:/ / sameoc.org/ FD/2015/CPEN/Bauer-SAME-CPEN-Day-2015-06-18-updated.pdf (accessed on 18 December 2018).

26. Kenny, J.F.; Barber, N.L.; Hutson, S.S.; Linsey, K.S.; Lovelace, J.K.; Maupin, M.A. Estimated Use of Water in the United States in 2005; U.S. Geological Survey Circular 1344: Reston, VA, USA.

27. IEA (International Energy Agency). Water for Energy: Is energy becoming a thirstier resource. In World Energy Outlook 2012; OECD/IEA: Paris, France, 2012. Available online: https://www.iea.org/media/ publications/weo/WEO_2012_Water_Excerpt.pdf (accessed on 18 December 2018).

28. Feeley, T.J.; Skone, T.J.; Stiegel, G.J.; McNemar, A.; Nemeth, M.; Schimmoller, B.; Murphy, J.T.; Manfredo, L. Water: A critical resource in the thermoelectric power industry. Energy 2008, 33, 1-11. [CrossRef]

29. Chapagain, A.K.; Hoekstra, A.Y. Water Footprints of Nations; Value of Water Research Report Series No. 16; UNESCO-IHE: Delft, The Netherlands, 2004. Available online: http:/ /www.waterfootprint.org/Reports / Report16.pdf (accessed on 18 December 2018).

30. Gerbens-Leenes, W.; Hoekstra, A.Y.; Van Der Meer, T.H. The water footprint of bioenergy. Proc. Natl. Acad. Sci. USA 2009, 106, 10219-10223. [CrossRef] [PubMed]

31. Mekonnen, M.M.; Hoekstra, A.Y. The green, blue and grey water footprint of crops and derived crop products. Hydrol. Earth Syst. Sci. 2011, 15, 1577-1600. [CrossRef]

32. Hoekstra, A.Y.; Mekonnen, M.M. The water footprint of humanity. Proc. Natl. Acad. Sci. 2012, 109, $3232-3237$. [CrossRef] [PubMed]

33. Egan, M. The Water Footprint Assessment Manual. Setting the Global Standard. Soc. Environ. Account. J. 2011, 31, 181-182. [CrossRef] 
34. Mekonnen, M.M.; Hoekstra, A.Y. The blue water footprint of electricity from hydropower. Hydrol. Earth Syst. Sci. 2012, 16, 179-187. [CrossRef]

35. Mekonnen, M.M.; Gerbens-Leenes, P.W.; Hoekstra, A.Y. The consumptive water footprint of electricity and heat: A global assessment. Environ. Sci. Water Res. Technol. 2015, 1, 285-297. [CrossRef]

36. Chini, C.M.; Djehdian, L.A.; Lubega, W.N.; Stillwell, A.S. Virtual water transfers of the US electric grid. Nat. Energy 2018, 3, 1115-1123. [CrossRef]

37. Carrillo, A.M.R.; Frei, C. Water: A key resource in energy production. Energy Policy 2009, 37, 4303-4312. [CrossRef]

38. Hardy, L.; Garrido, A.; Juana, L. Evaluation of Spain's Water-Energy Nexus. Int. J. Water Resour. Dev. 2012, 28, 151-170. [CrossRef]

39. Martín, D.S.; Rubio-Varas, M.D.M. Freshwater for Cooling Needs: A Long-Run Approach to the Nuclear Water Footprint in Spain. Ecol. Econ. 2017, 140, 146-156. [CrossRef]

40. Sesma-Martín, D.; Rubio-Varas, M.D.M. The weak data on the water-energy nexus in Spain. Water Policy 2019. [CrossRef]

41. Spanish Government; Ministerio de Medio AmbienteSecretaria de Estado de Aguas y Costas; Dirección General de Obras Hidráulicas y Calidad de Aguas. Libro Blanco del Agua; Centro de Publicaciones Secretaria General Técnica Ministerio de Medio Ambiente: Madrid, Spain, 2000; ISBN 84-8320-128-3. Available online: http:/ / hispagua.cedex.es/node/ 66958 (accessed on 27 February 2019).

42. Pinilla, V. Gestión y usos del agua en el siglo XX. Un estudio de caso: la Cuenca del Ebro. In Gestión y usos del agua en la Cuenca del Ebro en el siglo XX; Prensas Universitarias de Zaragoza: Zaragoza, Spain, 2008; pp. 39-96. ISBN 978-84-7733-997-7.

43. Benlloch, P.I.; Pérez, F.; Rabanaque, I.; Rodrigo, V. Condicionantes ecológicos para el desarrollo de la agricultura. In Gestión y usos del agua en la cuenca del Ebro en el siglo XX; Prensas Universitarias de Zaragoza: Zaragoza, Spain, 2008; ISBN 978-84-7733-997-7.

44. Barceló, D.; Petrovic, M. The Ebro River Basin. In The Handbook of Environmental Chemistry; Springer Verlag: Berlin, Germany, 2011; Volume 13, p. 434.

45. Boneta Carrera, M. El desarrollo de las infraestructuras hidráulicas en la cuenca catalana del Ebro durante el siglo XX. La hidroelectricidad. In Gestión y Usos del Agua en la Cuenca del Ebro en el Siglo XX; Prensas Universitarias de Zaragoza: Zaragoza, Spain, 2008; pp. 265-274. ISBN 978-84-7733-997-7.

46. Miana Escabosa, A.; Valero Ruiz, C. La Minería del Carbón en Aragón: su Historia, Métodos de Trabajo y Evolución Tecnológica; Tierra AC: Zaragoza, Spain, 2003; pp. 240-248. ISBN 84-932408-5-0.

47. ELEREBRO, Environmental Report. Available online: http://siun.navarra.es/documentosPDF/MPSIS/ 104084/104084_009.pdf (accessed on 18 December 2018).

48. Spanish Ministry of Industry and Energy. Study on the use of lignite in Teruel and Catalonia. Available online: http:/ /info.igme.es/SidPDF\%5C006000\%5C256\%5CTomo\%20I\%5C6256_0001.pdf. (accessed on 18 December 2018).

49. Macknick, J.; Newmark, R.; Heath, G.; Hallett, K.C. Review of Operational Water Consumption and Withdrawal Factors for Electricity Generating Technologies; National Renewable Energy Lab (NREL): Golden, CO, USA, 2011.

50. Macknick, J.; Newmark, R.; Hallett, K.C.; Heath, G. Operational water consumption and withdrawal factors for electricity generating technologies: a review of existing literature. Environ. Res. Lett. 2012, 7, 045802. [CrossRef]

51. Nettles-Anderson, S.; Macknick, J.; Meldrum, J.; Heath, G. Life cycle water use for electricity generation: a review and harmonization of literature estimates. Environ. Res. Lett. 2013, 8, 015031.

52. Spang, E.S.; Moomaw, W.R.; Gallagher, K.S.; Kirshen, P.H.; Marks, D.H. The water consumption of energy production: an international comparison. Environ. Res. Lett. 2014, 9, 105002. [CrossRef]

53. Confederación Hidrográfica del Ebro. Available online: http://http://www.chebro.es (accessed on 18 December 2018).

54. Moomaw, W.R.; Gallagher, K.S.; Kirshen, P.H.; Marks, D.H.; Spang, E.S. Multiple metrics for quantifying the intensity of water consumption of energy production. Environ. Res. Lett. 2014, 9, 105003.

55. Van Vliet, M.T.; Franssen, W.H.; Yearsley, J.R.; Ludwig, F.; Haddeland, I.; Lettenmaier, D.P.; Kabat, P. Global river discharge and water temperature under climate change. Glob. Environ. Chang. 2013, 23, 450-464. [CrossRef] 
56. Kaushal, S.S.; Likens, G.E.; Jaworski, N.A.; Pace, M.L.; Sides, A.M.; Seekell, D.; Belt, K.T.; Secor, D.H.; Wingate, R.L. Rising stream and river temperatures in the United States. Front. Ecol. Environ. 2010, 8, 461-466. [CrossRef]

57. Confederación Hidrográfica del Ebro. Plan Hidrológico del Ebro 2015-2021. Available online: http: / / www. chebro.es / contenido.visualizar.do?idContenido=34057\&idMenu=4281 (accessed on 18 December 2018).

58. De Stefano, L.; Hernández-Mora, N.; Cabello, V. Informe sobredatos abiertos en el sector del aguaFundación Botín, Observatorio Del Agua, Santanderp. 27. 2018, p. 27. Available online: https://www.fundacionbotin.org/89dguuytdfr276ed_uploads/Observatorio\%20Tendencias / PUBLICACIONES/MONOGRAFIAS/Datos_Abiertos_2018.pdf (accessed on 18 December 2018).

59. ENDESA, Environmental Reports. Available online: https://www.endesa.com/es/sostenibilidad/a201610gestion-ambiental.html (accessed on 18 December 2018).

60. IBERDROLA. Environmental Reports. Available online: https://www.iberdrola.com/sostenibilidad/medioambiente/gestion-medioambiental/certificaciones-verificaciones (accessed on 18 December 2018).

61. EDP HC Energía, Environmental Reports. Available online: https://www.sostenibilidadedp.es/ publicaciones/index_for_categoria/174 (accessed on 18 December 2018).

62. Galve Dolz, M. La Central térmica de Teruel. In El Agua, Vida y Paisaje en las Comarcas de Andorra-Sierra de Arcos y del Bajo Martín; CELAN, CEBM, Comarca de Andorra-Sierra de Arcos y Comarca del Bajo Martín: Teruel, Spain, 2007; p. 236.

(C) 2019 by the author. Licensee MDPI, Basel, Switzerland. This article is an open access article distributed under the terms and conditions of the Creative Commons Attribution (CC BY) license (http://creativecommons.org/licenses/by/4.0/). 